\title{
PENGARUH KONDISI SISTEM KERJA TERHADAP STRESS KERJA DENGAN MENGGUNAKAN MACROERGONOMIC ORGANIZATIONAL QUESTIONNARE SURVEY (MOQS)
}

\author{
Wahyu Ani Maulidiyah Sari*, Bambang Suhardi, I Wayan Suletra \\ Program Studi Teknik Industri, Fakultas Teknik, Universitas Sebelas Maret \\ Email: wahyuanims@gmail.com; bambangsuhardi@staff.uns.ac.id; suletra@staff.uns.ac.id
}

Artikel masuk : 10-12-2020

Artikel direvisi : 26-01-2021

Artikel diterima : 08-02-2021

*Penulis Korespondensi

\begin{abstract}
Abstrak -- Conarch Bangun Sejahtera merupakan perusahaan konsultan arsitektur yang bergerak dibidang desain bangunan dan konstruksi bangunan. Beban kerja mental yang tinggi dan kondisi sistem kerja yang tidak sesuai menyebabkan pekerja mengalami gejala stress kerja seperti timbulnya kebosanan dalam bekerja, kurangnya motivasi dan semangat dalam bekerja dan kekhawatiran terhadap karirnya dimasa depan. Penelitian ini bertujuan untuk mengetahui pengaruh dari komponen sistem kerja terhadap stress kerja. Metode yang digunakan adalah Macroergonomic Organizational Questionnare Survey (MOQS) dan dianalisis menggunakan analisis jalur (path analysis). Hasil penelitian ini menunjukkan bahwa terdapat pengaruh sangat sigifikan dari variabel sistem kerja secara simultan terhadap stress kerja. Variabel sistem kerja secara parsial mempunyai pengaruh terhadap stress kerja dengan menghitung kontribusi efektifnya menunjukkan bahwa pada variabel lingkungan fisik berkontribusi sebesar $7.82 \%$, variabel lingkungan sosial sebesar $15.08 \%$, variabel kondisi pekerjaan sebesar $30.53 \%$, variabel kondisi organisasi sebesar $10.89 \%$, variabel teknologi dan peralatan kerja sebesar $7.14 \%$ dan variabel karakteristik individu sebesar 11.94\%. Dari keenam variabel tersebut, diketahui bahwa variabel yang paling berpengaruh terhadap stress kerja adalah kondisi pekerjaan dan lingkungan sosial sehingga diberikan usulan perbaikan pada kedua variabel tersebut untuk mengurangi stress kerja.
\end{abstract}

Kata kunci: Analisis Jalur; MOQS; Sistem Kerja; Stress Kerja

\begin{abstract}
Conarch Bangun Sejahtera is an architectural consulting company engaged in building design and building construction. High mental workload and unsuitable work system conditions cause workers to experience symptoms of work stress such as boredom at work, lack of motivation and enthusiasm for work and worries about their future careers. This study aims to determine the effect of work system components on job stress. The method used is the Macroergonomic Organizational Questionnaire Survey (MOQS) and analyzed using path analysis. This study shows that there is very significant effect of work system variables simultaneously on job stress. Work system variables partially have an influence on job stress by calculating their effective contribution, indicating that the physical environment variable contributes $7.82 \%$, the social environment variable is $15.08 \%$, the work condition variable is $30.53 \%$, the organizational condition variable is $10.89 \%$, the technology variable and work equipment is $7.14 \%$ and individual characteristic variables is $11.94 \%$. Of the six variables, it is known that the variables that have the most influence on work stress are the conditions of work and the social environment, so suggestions are given to improve these two variables to reduce work stress.
\end{abstract}

Keywords: Path Analysis; MOQS; Work System; Work Stress

\section{PENDAHULUAN}

Conarch Bangun Sejahtera merupakan perusahaan konsultan arsitektur yang bergerak di bidang desain bangunan dan konstruksi bangunan yang berdiri sejak tahun 2002. Conarch
Bangun Sejahtera mempunyai beberapa divisi seperti divisi studio, divisi project, divisi support, dan divisi administrasi. Setiap divisi mempunyai target masing-masing yang harus diselesaikan berdasarkan waktu yang telah ditentukan. Namun 
dalam pelaksanaannya, seringkali target tersebut belum bisa terpenuhi.

Berdasarkan hasil wawancara yang dilakukan terhadap pekerja, diketahui bahwa hal ini dikarenakan waktu yang diberikan untuk menyelesaikan pekerjaan begitu singkat serta adanya revisi dan pertimbangan yang diberikan oleh pimpinan maupun klien. Selain itu, terdapat beberapa keluhan berkaitan dengan sistem kerja disana. Tuntutan untuk selalu berkonsentrasi dan fokus dalam bekerja serta kesempurnaan dalam hasil menyebabkan pekerja mengalami tekanan serta kekurangan motivasi dan semangat dalam bekerja. Tanggung jawab yang besar di dalam lingkungan kerja dan di luar lingkungan kerja juga menjadi beban bagi pekerja. Adanya ketidakpastian pekerjaan di masa depan dan pengembangan karir yang jelas membuat pekerja merasa khawatir dalam bekerja. Selain itu, rutinitas yang selalu sama dalam jangka waktu yang lama dan kurangnya tantangan dalam bekerja menyebabkan timbulnya rasa bosan pada pekerja.

Apabila hal ini dibiarkan terus-menerus maka dapat berpengaruh terhadap efektivitas dan produktivitas pekerja serta kepuasan dari pekerja maupun klien. Rasa bosan, rasa khawatir dan kekurangan motivasi serta semangat dalam bekerja merupakan indikasi adanya stress kerja pada pekerja (Setiyana, 2013). Stress kerja merupakan keadaan dimana terjadi ketegangan yang menyebabkan perubahan pada kondisi fisik, pikiran, serta emosi seorang pekerja (Siagian, 2003). Berdasarkan permasalahan tersebut, perlu dilakukan evaluasi berkaitan dengan pengaruh dari kondisi komponen sistem kerja terhadap stress kerja di Conarch Bangun Sejahtera.

Menurut Carayon \& Hoonakker (2004), komponen sistem kerja meliputi pekerjaan (task), kondisi organisasi, peralatan, teknologi, masalah lingkungan, dan karakteristik individu. Untuk mengevaluasi komponen sistem kerja tersebut, dapat menggunakan pendekatan ergonomi makro. Salah satu metode ergonomi makro yang dapat digunakan adalah Macroergonomic Organizational Questionnaire Survey (MOQS). MOQS merupakan metode yang dipakai untuk mendapatkan informasi mengenai berbagai aspek atau variabel dari sistem kerja (Carayon \& Smith, 2000). MOQS juga dapat dipakai untuk mendapatkan informasi tentang berbagai variabel keluaran seperti kepuasan kualitas kerja, stress fisik dan psikologis, kesehatan mental dan fisik, kinerja dan sikap.

Beberapa penelitian terkait MOQS telah dilakukan sebelumnya oleh Simanjuntak (2012) untuk mengetahui pengaruh komponen dari sistem kerja terhadap stress kerja baik secara parsial dan simultan. Tidak hanya berkaitan dengan stress kerja saja, MOQS juga dapat digunakan untuk mengetahui pengaruh dari komponen sistem kerja terhadap tingkat produktivitas di UKM Deriji Crafterus (Purnomo \& Ferdianto, 2011).

Untuk mengevaluasi hasil dari pengaruh variabel komponen sistem kerja terhadap stress kerja dari kuesioner MOQS menggunakan metode analisis jalur (path analysis). Penelitian ini bertujuan untuk mengetahui pengaruh dari kondisi komponen sistem kerja terhadap stress kerja pada pekerja sehingga dapat memberikan usulan perbaikan pada komponen sistem kerja yang berkontribusi tinggi terhadap stress kerja agar dapat mengurangi resiko stress kerja pada karyawan di Conarch Bangun Sejahtera.

\section{METODE PENELITIAN}

Metode pengumpulan data pada penelitian dilakukan dengan observasi secara langsung, wawancara serta penyebaran kuesioner. Kuesioner diberikan kepada seluruh pekerja Conarch Bangun Sejahtera yang berjumlah 16 orang (Tabel 1).

Tabel 1. Profil Pekerja Conarch Bangun Sejahtera

\begin{tabular}{|c|c|c|c|c|}
\hline $\begin{array}{l}\text { Nama } \\
\text { (Inisial) }\end{array}$ & $\begin{array}{c}\text { Jenis } \\
\text { Kelamin }\end{array}$ & Umur & $\begin{array}{c}\text { Pendidikan } \\
\text { Terakhir }\end{array}$ & Jabatan \\
\hline TR & Perempuan & 25 & S1 Arsitektur & $\begin{array}{l}\text { Koordinator } \\
\text { Arsitek }\end{array}$ \\
\hline B & Laki-laki & 41 & S1 Arsitektur & Senior Arsitek \\
\hline AIP & Perempuan & 24 & S1 Arsitektur & Junior Arsitek \\
\hline RAP & Perempuan & 25 & S1 Arsitektur & Junior Arsitek \\
\hline IM & Laki-laki & 30 & S1 Arsitektur & Junior Arsitek \\
\hline FRE & Laki-laki & 23 & S1 Arsitektur & 3D Visualisasi \\
\hline MA & Laki-laki & 25 & $\begin{array}{l}\text { S1 Desain } \\
\text { Interior }\end{array}$ & Desain Interior \\
\hline $\mathrm{FO}$ & Perempuan & 25 & $\begin{array}{l}\text { S1 Desain } \\
\text { Interior }\end{array}$ & Desain Interior \\
\hline $\mathrm{KZF}$ & Laki-laki & 21 & SMK & Drafter \\
\hline NNA & Laki-laki & 21 & SMK & Drafter \\
\hline AK & Laki-laki & 24 & $\begin{array}{l}\text { S1 Teknik } \\
\text { Sipil }\end{array}$ & Estimator \\
\hline PAP & Laki-laki & 29 & SMK & $\begin{array}{l}\text { Pelaksana } \\
\text { Lapangan }\end{array}$ \\
\hline PPWW & Perempuan & 24 & $\begin{array}{l}\text { S1 Pend. } \\
\text { B.Inggris }\end{array}$ & $\begin{array}{l}\text { Digital } \\
\text { Marketing }\end{array}$ \\
\hline PK & Laki-laki & 37 & Diploma & Teknisi \\
\hline SA & Laki-laki & 34 & $\begin{array}{l}\text { S1 Desain } \\
\text { Interior }\end{array}$ & Desain Interior \\
\hline SW & Perempuan & 20 & SMK & Administrasi \\
\hline
\end{tabular}

Kuesioner yang disebarkan adalah NASATLX dan kuesioner MOQS. Kuesioner NASA-TLX digunakan untuk mengukur beban kerja mental pekerja. Dimensi yang diukur dalam kuesioner tersebut adalah Mental Demand (MD), Temporal Demand (TD), Physical Demand (PD), Effort (EF), Own Performance (OP), dan Frustration Level 
(FR). Nilai beban kerja mental tersebut akan menjadi dasar dari hipotesis yang berkaitan dengan kondisi sistem kerja terhadap stress kerja yang dialami pekerja. Hasil dari NASA-TLX akan menjadi dasar pengembangan MOQS.

Dalam pengembangan kuesioner MOQS terdiri dari tiga langkah, yaitu:

a. Konseptualisasi

Penentuan konsep yang akan dievaluasi oleh MOQS, yaitu stress kerja yang dialami oleh pekerja dengan komponen sistem kerja berupa lingkungan fisik, lingkungan sosial, kondisi pekerjaan, teknologi dan peralatan kerja, kondisi organisasi, dan karakteristik individu.

b. Operasionalisasi

Operasionalisasi adalah menjelaskan konsep variabel dari masing-masing komponen sistem kerja dan menentukan sumber kuesioner yang digunakan yaitu berasal dari NIOSH Generic Job Stress Questionnaire, Job Stress Survei, dan beberapa penelitianpenelitian yang menjadi studi literatur.

c. Penyusunan kuesioner.

Penyusunan kuesioner terdiri dari identitas responden, petunjuk pengisian, dan susunan pernyataan.

Hasil dari kuesioner MOQS kemudian dilakukan pengujian validitas dan reliabilitas dan dianalisis menggunakan analisis jalur. Langkahlangkah dalam pengolahan data adalah merumuskan hipotesis dan model awal, menghitung skor variabel dengan Methods of Successive Internal (MSI), uji asumsi klasik, menghitung analisis regresi, menghitung koefisien jalur, menguji hipotesis, menentukan variabel paling berpengaruh. Variabel yang telah dianalisis dengan menggunakan analisis jalur kemudian diberikan usulan perbaikan. Usulan perbaikan difokuskan pada variabel yang paling berpengaruh terhadap stress kerja.

\section{HASIL DAN PEMBAHASAN Pengukuran Beban Kerja Mental}

Dari hasil pengukuran beban kerja mental menggunakan NASA-TLX diketahui jika rata-rata beban kerja mental yang dialami pekerja adalah sebesar 73.271 dan hasil tersebut tergolong tinggi. Semakin tinggi beban kerja mental yang dialami pekerja, maka semakin tinggi pula resiko pekerja mengalami stress kerja. Bekerja dibawah tekanan waktu untuk mencapai target dan tuntutan kesempurnaan dalam hasil juga menjadi penyebab dari stress kerja (Pertiwi et al., 2017). Nilai beban kerja mental tersebut kemudian dijadikan sebagai dasar dari perumusan hipotesis yang berkaitan dengan pengaruh komponen sistem kerja terhadap stress kerja yang dialami pekerja sehingga perlu dilakukan evaluasi untuk mengetahui komponen apa saja dari sistem kerja yang dapat berpengaruh dan menjadi penyebab dari stress kerja dengan menggunakan Macroergonomic Organizational Questionnaire Survey (MOQS).

\section{Pengujian Validitas dan Reliabilitas Kuesioner MOQS}

Uji validitas adalah uji statistik yang bertujuan untuk menetapkan tingkat kevalidan dan ketepatan sebuah item pernyataan pada kuesioner yang berguna untuk mengukur variabel yang diamati. Uji validitas ini diukur menggunakan aplikasi statistika SPSS 25. Valid atau tidaknya suatu pernyataan dapat ditentukan dengan membandingkan nilai korelasi $(r)_{\text {tabel }}$ dengan nilai

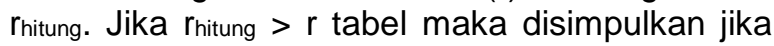
pernyataan tersebut valid dan jika rhitung $<$ rtabel maka pernyataan tersebut tidak valid. Uji validitas dalam penelitian ini menggunakan nilai $r_{\text {tabel }}$ sebesar 0.497. Berdasarkan hasil penelitian, terdapat dua belas pernyataan yang tidak valid dari 120 pernyataan. Dua belas item pernyataan tersebut selanjutnya dihapus dan tidak digunakan dalam proses berikutnya.

Uji reliabilitas adalah uji statistik yang berguna untuk menentukan seberapa jauh hasil pengukuran jika menggunakan objek yang sama, maka dapat menghasilkan data yang sama (Sugiyono, 2018). Uji reliabilitas ini diukur menggunakan aplikasi SPSS 25. Variabel dapat dikatakan reliabel jika koefisien Cronbach's Alpha $>$ rtabel (0.497) dan apabila koefisien Cronbach's Alpha < rtabel (0.497) maka tidak reliabel. Tabel 2 berikut menunjukkan hasil uji reliabilitas pada kuesioner MOQS.

Tabel 2. Hasil Uji Reliabilitas

\begin{tabular}{cccc}
\hline Variabel & $\begin{array}{c}\text { Nilai } \\
\text { Cronbach } \\
\text { Alfa }\end{array}$ & $\begin{array}{c}\text { Nilai R } \\
\text { tabel }\end{array}$ & Ket. \\
\hline $\begin{array}{c}\text { Lingkungan } \\
\text { Fisik }\end{array}$ & 0.781 & 0.497 & Reliabel \\
$\begin{array}{c}\text { Lingkungan } \\
\text { Sosial }\end{array}$ & 0.677 & 0.497 & Reliabel \\
$\begin{array}{c}\text { Teknologi dan } \\
\text { Peralatan } \\
\text { Kerja } \\
\text { Kondisi }\end{array}$ & 0.705 & 0.497 & Reliabel \\
$\begin{array}{c}\text { Pekerjaan } \\
\text { Kondisi } \\
\text { Organisasi } \\
\text { Karakteristik } \\
\text { Individu }\end{array}$ & 0.662 & 0.497 & Reliabel \\
Stress Kerja & 0.585 & 0.497 & Reliabel \\
\hline
\end{tabular}




\section{Rekapitulasi Skor Variabel}

Dalam kuesioner MOQS, terdapat enam variabel bebas yang dievaluasi yaitu komponen dari sistem kerja yang meliputi: lingkungan fisik $\left(X_{1}\right)$, lingkungan sosial $\left(X_{2}\right)$, kondisi pekerjaan $\left(X_{3}\right)$, kondisi organisasi $\left(X_{4}\right)$, teknologi dan peralatan kerja $\left(\mathrm{X}_{5}\right)$, karakteristik individu $\left(\mathrm{X}_{6}\right)$ dan variabel terikat berupa variabel keluaran yaitu stress kerja yang dialami pekerja $(\mathrm{Y})$. Tabel 3 merupakan hasil rekapitulasi skor semua variabel yang telah diubah dari data ordinal menjadi data interval menggunakan Methods of Successive Internal (MSI).

Tabel 3. Rekapitulasi Skor Semua Variabel

\begin{tabular}{cccccccc}
\hline $\begin{array}{c}\text { Respon } \\
\text { den }\end{array}$ & $\begin{array}{c}\text { LF } \\
(\mathbf{X})\end{array}$ & $\begin{array}{c}\text { LS } \\
(\mathbf{X 2})\end{array}$ & $\begin{array}{c}\text { KP } \\
(\mathbf{X 3})\end{array}$ & $\begin{array}{c}\text { KO } \\
(\mathbf{X 4})\end{array}$ & $\begin{array}{c}\text { TP } \\
(\mathbf{X 5})\end{array}$ & $\begin{array}{c}\text { KI } \\
(\mathbf{X 6})\end{array}$ & $\begin{array}{c}\text { SK } \\
(\mathbf{Y})\end{array}$ \\
\hline $\mathbf{1}$ & 41.29 & 56.90 & 60.83 & 71.55 & 18.93 & 27.33 & 80.04 \\
$\mathbf{2}$ & 41.55 & 53.87 & 60.29 & 75.19 & 13.96 & 28.11 & 70.09 \\
$\mathbf{3}$ & 48.87 & 77.59 & 73.92 & 111.60 & 20.76 & 27.87 & 99.06 \\
$\mathbf{4}$ & 53.34 & 63.83 & 58.34 & 76.12 & 18.93 & 26.79 & 69.55 \\
$\mathbf{5}$ & 41.81 & 65.15 & 55.85 & 115.91 & 11.32 & 33.24 & 50.06 \\
$\mathbf{6}$ & 51.51 & 67.64 & 66.32 & 73.99 & 16.45 & 39.26 & 54.76 \\
$\mathbf{7}$ & 72.73 & 65.81 & 58.74 & 129.01 & 18.93 & 42.53 & 52.16 \\
$\mathbf{8}$ & 49.95 & 62.16 & 68.56 & 91.70 & 16.45 & 35.06 & 56.19 \\
$\mathbf{9}$ & 57.65 & 64.10 & 70.67 & 91.70 & 18.93 & 32.58 & 90.13 \\
$\mathbf{1 0}$ & 72.73 & 54.12 & 58.08 & 95.36 & 21.42 & 28.11 & 65.36 \\
$\mathbf{1 1}$ & 47.43 & 69.85 & 48.63 & 80.82 & 16.45 & 32.58 & 61.81 \\
$\mathbf{1 2}$ & 49.68 & 68.96 & 55.20 & 78.61 & 16.45 & 30.75 & 57.64 \\
$\mathbf{1 3}$ & 47.20 & 61.50 & 56.64 & 81.09 & 18.93 & 30.09 & 59.98 \\
$\mathbf{1 4}$ & 52.82 & 57.83 & 53.87 & 78.99 & 17.61 & 29.43 & 63.28 \\
$\mathbf{1 5}$ & 45.37 & 76.69 & 59.28 & 76.78 & 13.96 & 36.89 & 54.27 \\
$\mathbf{1 6}$ & 45.88 & 56.22 & 63.05 & 73.99 & 13.30 & 29.43 & 58.81 \\
\hline
\end{tabular}

\section{Uji Asumsi Klasik}

Uji normalitas merupakan uji statistik yang digunakan untuk menentukan apakah pada model regresi, variabel independen dan dependennya berdistribusi normal atau tidak (Ghozali, 2018). Uji normalitas ini diukur dengan aplikasi statistika SPSS 25. Data dapat dinyatakan berdistribusi normal jika uji Kolmogorov-Smirnov > 0.05. Hasil uji normalitas dari hasil rekapitulasi skor variabel kuesioner yang menunjukkan bahwa data penelitian berdistribusi normal dikarenakan nilai signifikansi > 0.05 (Tabel 4).

Uji multikolinieritas adalah uji statistik yang digunakan untuk menentukan apakah terdapat interkorelasi atau kolinearitas antara variabel bebas pada sebuah model. Uji multikolinieritas dapat ditentukan melalui nilai toleransi dan Variance Inflation Factor (VIF). Apabila nilai toleransi $>0.1$ dan nilai $\mathrm{VIF}<10$, maka dikatakan tidak ada multikolinieritas dalam model tersebut. Hasil uji multikolinieritas dari rekapitulasi skor variabel kuesioner yang menunjukkan semua variabel komponen sistem kerja memiliki nilai toleransi $>0.1$ dan nilai VIF $<$ 10 sehingga dapat dinyatakan bahwa tidak ada multikolinieritas antar variabel bebas pada model penelitian (Tabel 5).

Tabel 4. Hasil Uji Normalitas

\begin{tabular}{|c|c|c|}
\hline & & $\begin{array}{c}\text { Unstandardized } \\
\text { Residual }\end{array}$ \\
\hline $\mathrm{N}$ & & 16 \\
\hline \multirow[t]{2}{*}{ Normal Parameters ${ }^{a, b}$} & Mean & .0000000 \\
\hline & Std. Deviation & 6.25778569 \\
\hline Most Extreme & Absolute & .134 \\
\hline \multirow[t]{2}{*}{ Differences } & Positive & .134 \\
\hline & Negative & -.126 \\
\hline Test Statistic & & .134 \\
\hline Asymp. Sig. (2-tailed) & & $.200^{c, d}$ \\
\hline \multicolumn{3}{|c|}{$\begin{array}{l}\text { a. Test distribution is Normal. } \\
\text { b. Calculated from data. } \\
\text { c. Lilliefors Significance Correction. } \\
\text { d. This is a lower bound of the true significance. }\end{array}$} \\
\hline
\end{tabular}

Tabel 5. Hasil Uji Multikolinieritas

\begin{tabular}{|c|c|c|c|c|c|c|c|c|}
\hline & \multirow{2}{*}{ Model } & \multicolumn{3}{|c|}{$\begin{array}{l}\text { Unstandardized Standardized } \\
\text { Coefficients Coefficients }\end{array}$} & \multirow{2}{*}{$\mathbf{t}$} & \multirow{2}{*}{ Sig. } & \multicolumn{2}{|c|}{$\begin{array}{l}\text { Collinearity } \\
\text { Statistics }\end{array}$} \\
\hline & & B & $\begin{array}{l}\text { Std. } \\
\text { Error }\end{array}$ & Beta & & & Tolerance & VIF \\
\hline & (Constant) & 8.299 & 28.571 & & 290 & .778 & & \\
\hline \multirow[t]{6}{*}{1} & $\mathrm{X} 1$ & -.318 & .438 & -.218 & -.726 & .486 & .251 & 3.980 \\
\hline & $\mathrm{X} 2$ & .298 & .377 & .155 & .791 & .449 & .588 & 1.699 \\
\hline & X3 & .927 & .346 & .442 & 2.681 & .025 & .834 & 1.199 \\
\hline & X4 & 102 & .156 & . 127 & .654 & .529 & .599 & 1.669 \\
\hline & X5 & 2.236 & 1.306 & .453 & 1.713 & .121 & .323 & 3.092 \\
\hline & $\mathrm{X} 6$ & -1.540 & .708 & -.508 & -2.175 & .058 & .415 & 2.408 \\
\hline
\end{tabular}

Uji heteroskedastisitas merupakan uji statistik yang berguna untuk menentukan apakah ada ketidaksamaan variansi dari residual untuk semua penelitian. Untuk mengetahui ada atau tidaknya heteroskedastisitasdapat ditunjukkan dengan nilai signifikansi. Jika nilai signifikansi > 0.05 , maka tidak ada heteroskedastisitas dalam model tersebut. Hasil uji heteroskedastisitas dari rekapitulasi skor variabel kuesioner yang menunjukkan bahwa semua variabel komponen sistem kerja mempunyai nilai signifikansi $>0.05$ sehingga dapat dikatakan bahwa tidak ada heteroskedastisitas dalam model penelitian (Tabel $6)$.

Tabel 6. Hasil Uji Heteroskedastisitas

\begin{tabular}{|c|c|c|c|c|c|c|}
\hline & \multirow{2}{*}{ Model } & \multicolumn{2}{|c|}{$\begin{array}{l}\text { Unstandardized } \\
\text { Coefficients }\end{array}$} & \multirow{2}{*}{$\begin{array}{c}\text { Standardized } \\
\text { Coefficients } \\
\text { Beta }\end{array}$} & \multirow{2}{*}{$\mathbf{t}$} & \multirow{2}{*}{ Sig. } \\
\hline & & B & $\begin{array}{l}\text { Std. } \\
\text { Error }\end{array}$ & & & \\
\hline \multirow[t]{7}{*}{1} & (Constant) & 4.957 & 15.665 & & .316 & .759 \\
\hline & $\mathrm{X} 1$ & -.123 & .240 & -.307 & -.511 & .621 \\
\hline & $\mathrm{X} 2$ & -.235 & .207 & -.447 & 1.139 & .284 \\
\hline & $\mathrm{X} 3$ & .079 & .190 & .138 & .417 & .686 \\
\hline & $X 4$ & -.015 & .086 & -.070 & -.180 & .861 \\
\hline & $\times 5$ & .515 & .716 & .381 & .719 & .490 \\
\hline & $\mathrm{X} 6$ & .281 & .388 & .338 & .724 & .487 \\
\hline
\end{tabular}




\section{Perhitungan Analisis Regresi}

Dari hasil data kuesioner, kemudian dilakukan perhitungan analisis regresi (Tabel 7 , Tabel 8, dan Tabel 9). Hal ini menunjukkan beban kerja mental secara simultan mempunyai pengaruh terhadap terjadinya stress kerja sebesar $83,8 \%$. $16,4 \%$ pengaruh stress kerja terjadi dari faktor-faktor lain selain variabel penelitian ini.

Tabel 7. Model Summary

\begin{tabular}{lcccc}
\hline Model & $\mathbf{R}$ & $\begin{array}{c}\mathbf{R} \\
\text { Square }\end{array}$ & $\begin{array}{c}\text { Adjusted R } \\
\text { Square }\end{array}$ & $\begin{array}{c}\text { Std. Error } \\
\text { of the } \\
\text { Estimate }\end{array}$ \\
\hline 1 & $.915^{\mathrm{a}}$ & .838 & .730 & 7.20008 \\
\hline \multicolumn{4}{l}{ a. Predictors: (Constant), X6, X5, X3, X4, X2, X1 } \\
\hline
\end{tabular}

Tabel 8. Anova

\begin{tabular}{llrrrrr}
\hline & Model & $\begin{array}{r}\text { Sum of } \\
\text { Squares }\end{array}$ & df & $\begin{array}{c}\text { Mean } \\
\text { Square }\end{array}$ & F & Sig. \\
\hline 1 & Regression & 2413.635 & 6 & 402.273 & 7.760 & $.004^{\mathrm{b}}$ \\
& Residual & 466.571 & 9 & 51.841 & & \\
\multicolumn{1}{l}{ Total } & 2880.206 & 15 & & & \\
\hline a. Dependent Variable: Y & & & & \\
b. Predictors: (Constant), X6, X5, X3, X4, X2, X1 & \\
\hline
\end{tabular}

Tabel 9. Koefisien Regresi

\begin{tabular}{|c|c|c|c|c|c|c|}
\hline & \multirow{2}{*}{ Model } & \multicolumn{2}{|c|}{$\begin{array}{l}\text { Unstandardized } \\
\text { Coefficients }\end{array}$} & \multirow{2}{*}{$\begin{array}{c}\text { Standardized } \\
\text { Coefficients } \\
\text { Beta }\end{array}$} & \multirow{2}{*}{$t$} & \multirow{2}{*}{ Sig. } \\
\hline & & B & $\begin{array}{l}\text { Std. } \\
\text { Error }\end{array}$ & & & \\
\hline \multirow[t]{7}{*}{1} & (Constant) & 67.060 & 32.380 & & 2.371 & .048 \\
\hline & $\mathrm{X} 1$ & .011 & .264 & .007 & 2.140 & .050 \\
\hline & $\mathrm{X} 2$ & .377 & .315 & .196 & 2.196 & .026 \\
\hline & X3 & .938 & .300 & .447 & 3.128 & .012 \\
\hline & $\times 4$ & .113 & .139 & .140 & 2.813 & .044 \\
\hline & $\times 5$ & -.319 & .130 & -.374 & -2.454 & .036 \\
\hline & $\times 6$ & -.217 & .491 & -.716 & -4.423 & .002 \\
\hline
\end{tabular}

\section{Perhitungan Analisis Jalur}

Dari hasil perhitungan regresi, dapat diketahui bahwa:

Nilai Koefisien Determinasi $\left(R^{2}\right)=0,838$

$$
\varepsilon_{y}=\sqrt{1-R^{2}}=\sqrt{1-0,838=0,402}
$$

Persamaan pada analisis jalur sebagai berikut:

$Y=\rho_{y x 1} X_{1}+\rho_{y x 2} X_{2}+\rho_{y x 3} X_{3}+\rho_{y x 4} X_{4}+\rho_{y x 5} X_{5}+\rho_{y x 6} X_{6}+\varepsilon$

$Y=0,011 X_{1}+0,377 X_{2}+0,938 X_{3}+0,113 X_{4}-0,319 X_{5}-0,217 X_{6}+0,402$

Diagram jalur yang terbentuk dapat dilihat pada gambar 1.

\section{Pengujian Analisis Jalur}

a. Pengujian Secara Simultan

$$
\begin{aligned}
H_{0}: & \rho_{y x 1}=\rho_{y x 2}=\cdots=\rho_{y x i}=0 \quad \text { (Tidak ter- } \\
& \text { dapat pengaruh dari komponen sistem } \\
& \text { kerja terhadap stress kerja). } \\
H_{1}: & \rho_{y x 1}=\rho_{y x 2}=\cdots=\rho_{y x i} \neq 0 \quad \text { (Terdapat } \\
& \text { pengaruh dari komponen sistem kerja } \\
& \text { terhadap stress kerja). }
\end{aligned}
$$

Berdasarkan Tabel 6 ANOVA didapatkan nilai $F_{\text {hitung }}$ sebesar 7,760 dan nilai signifikansi sebesar 0,004 . Sedangkan Nilai $F_{\text {tabel }}$ sebesar 3,37 dan nilai taraf nyata $(\alpha)$ sebesar 0.05 . Karena nilai $F_{\text {hitung }}>F_{\text {tabel }}$ dan nilai signifikansi $<$ 0.05 , maka $\mathrm{H}_{0}$ ditolak dan $\mathrm{H}_{1}$ diterima sehingga dapat dikatakan bahwa terdapat pengaruh sangat signifikan dari komponen sistem kerja sebagai satu kesatuan terhadap stress kerja.

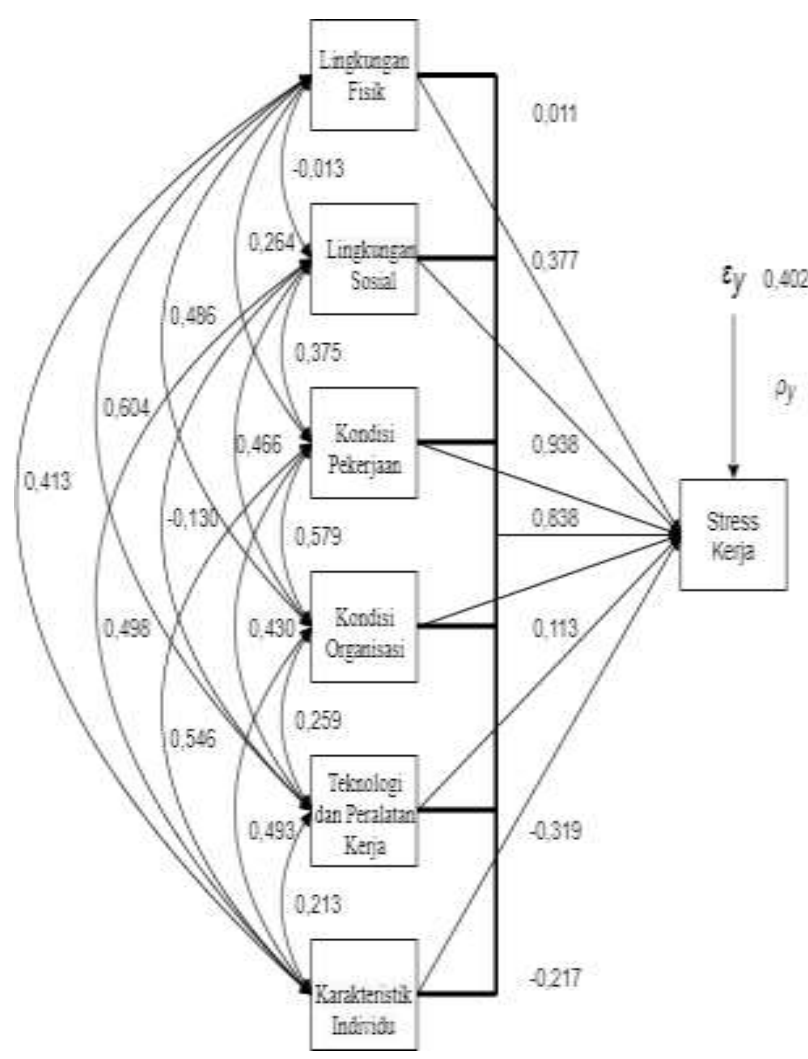

Gambar 1. Diagram Jalur

b. Pengujian Secara Parsial

- Pengujian pengaruh X1 (Lingkungan Fisik) terhadap Y (Stress Kerja)

$H_{0}: \rho_{y x 1}=0$ (lingkungan fisik tidak berpengaruh terhadap stress kerja yang dialami pekerja)

$H_{1}: \rho_{y x 1} \neq 0$ (lingkungan fisik berpengaruh terhadap stress kerja yang dialami pekerja)

Berdasarkan Tabel 9 diperoleh nilai thitung untuk variabel $\mathrm{X} 1$ sebesar 2,140 dan nilai signifikansi sebesar 0,050 . Dengan menggunakan tabel sebaran $\mathrm{t}$ untuk $\mathrm{n}=16$ dan $\alpha=0,05$, maka diperoleh wilayah kritik $\mathrm{t}<-\alpha / 2$ dan $\mathrm{t}>-\alpha / 2$, $\mathrm{t}<$ $-2,144$ dan $t>2,144$. Karena nilai thitung $>2,144$ dan tidak berada di wilayah kritik maka $\mathrm{H} 0$ ditolak dan $\mathrm{H} 1$ diterima sehingga dapat disimpulkan bahwa lingkungan fisik (X1) berpengaruh terhadap stress kerja yang dialami pekerja. 
- Pengujian pengaruh X2 (Lingkungan Sosial) terhadap Y (Stress Kerja)

$H_{0}: \rho_{y x 2}=0$ (lingkungan sosial tidak berpengaruh terhadap stress kerja yang dialami pekerja)

$H_{1}: \rho_{y x 2} \neq 0$ (lingkungan sosial berpengaruh terhadap stress kerja yang dialami pekerja)

Nilai thitung untuk variabel X2 sebesar 2,196 dan nilai signifikansi sebesar 0,026 (Tabel 9). Dengan menggunakan tabel sebaran $\mathrm{t}$ untuk $\mathrm{n}=$ 16 dan $\alpha=0,05$, diperoleh wilayah kritik $\mathrm{t}<-\alpha / 2$ dan $\mathrm{t}>-\alpha / 2, \mathrm{t}<-2,144$ dan $\mathrm{t}>2,144$. Karena nilai thitung $>2,144$ dan tidak berada di wilayah kritik maka $\mathrm{H} 0$ ditolak dan $\mathrm{H} 1$ diterima sehingga dapat disimpulkan bahwa lingkungan sosial (X2) berpengaruh terhadap stress kerja yang dialami pekerja.

- Pengujian pengaruh X3 (Kondisi Pekerjaan) terhadap Y (Stress Kerja)

$H_{0}: \rho_{y x 3}=0$ (kondisi pekerjaan tidak berpengaruh terhadap stress kerja yang dialami pekerja)

$H_{1}: \rho_{y x 3} \neq 0$ (kondisi pekerjaan berpengaruh terhadap stress kerja yang dialami pekerja)

Berdasarkan Tabel 9 diperoleh nilai thitung untuk variabel $X 3$ sebesar 3,128 dan nilai signifikansi sebesar 0,012 . Dengan menggunakan tabel sebaran t untuk $n=16$ dan $\alpha=0,05$, maka diperoleh wilayah kritik $\mathrm{t}<-\alpha / 2$ dan $\mathrm{t}>-\alpha / 2$, $\mathrm{t}<$ $-2,144$ dan $t>2,144$. Karena nilai thitung $>2,144$ dan tidak berada di wilayah kritik maka $\mathrm{HO}$ ditolak dan $\mathrm{H} 1$ diterima sehingga dapat disimpulkan bahwa kondisi pekerjaan (X3) berpengaruh terhadap stress kerja yang dialami pekerja.

- Pengujian pengaruh X4 (Kondisi Organisasi) terhadap Y (Stress Kerja)

$H_{0}: \rho_{y x 4}=0$ (kondisi organisasi tidak berpengaruh terhadap stress kerja yang dialami pekerja)

$H_{1}: \rho_{y x 4} \neq 0$ (kondisi organisasi berpengaruh terhadap stress kerja yang dialami pekerja)

Nilai thitung untuk variabel X4 sebesar 2,813 dan nilai signifikansi sebesar 0,044 (Tabel 9). Dengan menggunakan tabel sebaran $\mathrm{t}$ untuk $\mathrm{n}=$ 16 dan $\alpha=0,05$, maka diperoleh wilayah kritik $\mathrm{t}<$ $-\alpha / 2$ dan $\mathrm{t}>-\alpha / 2, \mathrm{t}<-2,144$ dan $\mathrm{t}>2,144$. Karena nilai thitung $>2,144$ dan tidak berada di wilayah kritik maka $\mathrm{H} 0$ ditolak dan $\mathrm{H} 1$ diterima sehingga dapat disimpulkan bahwa kondisi organisasi (X4) berpengaruh terhadap stress kerja yang dialami pekerja.
Pengujian pengaruh X5 (Peralatan dan Teknologi Kerja) terhadap Y (Stress Kerja)

$H_{0}: \rho_{y x 5}=0$ (peralatan dan teknologi kerja tidak berpengaruh terhadap stress kerja yang dialami pekerja)

$H_{1}: \rho_{y x 5} \neq 0$ (peralatan dan teknologi kerja berpengaruh terhadap stress kerja yang dialami pekerja)

Berdasarkan Tabel 9 diperoleh nilai thitung untuk variabel $X 5$ sebesar $-2,454$ dan nilai signifikansi sebesar 0,036 . Dengan menggunakan tabel sebaran $\mathrm{t}$ untuk $\mathrm{n}=16$ dan $\alpha=0,05$, maka diperoleh wilayah kritik $\mathrm{t}<-\alpha / 2$ dan $\mathrm{t}>-\alpha / 2, \mathrm{t}<$ $-2,144$ dan $t>2,144$. Karena nilai thitung $<-2,144$ dan tidak berada di wilayah kritik maka $\mathrm{HO}$ ditolak dan $\mathrm{H} 1$ diterima sehingga peralatan dan teknologi kerja (X5) berpengaruh terhadap stress kerja yang dialami pekerja.

Pengujian pengaruh X6 (Karakteristik Individu) terhadap Y (Stress Kerja)

$H_{0}: \rho_{y x 6}=0$ (karakteristik individu tidak berpengaruh terhadap stress kerja yang dialami pekerja)

$H_{1}: \rho_{y x 6} \neq 0 \quad$ (karakteristik individu berpengaruh terhadap stress kerja yang dialami pekerja)

Nilai thitung untuk variabel X6 sebesar $-4,423$ dan nilai signifikansi sebesar 0,002 (Tabel 9). Dengan menggunakan tabel sebaran $\mathrm{t}$ untuk $\mathrm{n}=$ 16 dan $\alpha=0,05$, maka diperoleh wilayah kritik $\mathrm{t}<$ $-\alpha / 2$ dan $\mathrm{t}>-\alpha / 2, \mathrm{t}<-2,144$ dan $\mathrm{t}>2,144$. Karena nilai thitung $<-2,144$ dan tidak berada di wilayah kritik maka $\mathrm{HO}$ ditolak dan $\mathrm{H} 1$ diterima sehingga dapat disimpulkan bahwa karakteristik individu (X6) berpengaruh terhadap stress kerja yang dialami pekerja.

\section{Penentuan Variabel Paling Berpengaruh}

Besar pengaruh atau sumbangan efektif (SE) setiap variabel komponen sistem kerja terhadap stress kerja (Lufri, 2004).

$S E: \beta \times y_{i j} \times 100 \%$

Secara keseluruhan, dari keenam variabel, terdapat dua variabel yang berpengaruh signifikan dan sangat dominan terhadap stress kerja, yaitu kondisi pekerjaan $(X 3)$ sebesar $30,53 \%$ dan lingkungan sosial (X2) sebesar $15,08 \%$ (Tabel 10). Kondisi Organisasi (X4) dan Karakteristik Individu (X6) masing-masing mempengaruhi stress kerja sebesar $11 \%$. Lingkungan Fisik (X1) dan Peralatan dan Teknologi Kerja (X5) merupakan variabel yang memiliki pengaruh paling kecil terhadap stress kerja. 
Tabel 10. Pengaruh Variabel terhadap Stress Kerja

\begin{tabular}{lccr}
\hline Variabel & $\begin{array}{c}\text { Koef. } \\
\text { Regresi } \\
(\boldsymbol{\beta})\end{array}$ & $\begin{array}{c}\text { Koef. } \\
\text { Korelasi } \\
\left(y_{i j}\right)\end{array}$ & \multicolumn{1}{c}{$\begin{array}{c}\text { Sum. } \\
\text { Efektif } \\
(\text { SE) }\end{array}$} \\
\hline X1 & 0,170 & 0,460 & $7.82 \%$ \\
X2 & 0,396 & 0,381 & $15,08 \%$ \\
X3 & 0,447 & 0,683 & $30,53 \%$ \\
X4 & 0,240 & 0,454 & $10,89 \%$ \\
X5 & $-0,374$ & -0.191 & $7,14 \%$ \\
X6 & $-0,316$ & -0.378 & $11,94 \%$ \\
Xi ;i=1-6 - & & & 0,838 \\
\hline
\end{tabular}

\section{Usulan Perbaikan}

Usulan perbaikan diberikan untuk variabel yang paling berpengaruh berdasarkan diagram jalur. Usulan perbaikan dibuat berdasarkan studi literatur dan penyesuaian terhadap kondisi perusahaan. Berikut merupakan usulan perbaikan dari indikator-indikator yang ada dalam variabel indikator kondisi pekerjaan dan indikator lingkungan sosial.

Usulan perbaikan untuk kondisi pekerjaan yang membutuhkan fokus dan konsentrasi tinggi adalah perusahaan memberikan waktu coffee break atau tea break selama $\pm 10-15$ menit di selasela jam kerja. Pemberian waktu coffee break atau tea break dapat meningkatkan kekuatan kelompok sosial di tempat kerja yang bermanfaat bagi produktivitas dalam perusahaan (Stroebaek, 2013; Waber et al., 2010). Selain itu dapat dilakukan dengan mendengarkan musik pada saat bekerja terutama musik dengan tempo yang lambat dan menggunakan kursi ergonomis yang sesuai dengan kriteria untuk memenuhi kebutuhan dan kenyamanan pekerja saat duduk dan bekerja.

Perbaikan untuk kondisi pekerjaan yang menuntut kesempurnaan dalam hasil dapat dilakukan dengan melakukan perbaikan berkelanjutan (continuous improvement) yang melibatkan seluruh elemen organisasi dengan metode PDCA (Plan-Do-Check-Action) untuk meningkatkan kualitas dalam pekerjaan. Metode PDCA juga dilakukan untuk mengurangi waktu dan energi yang terbuang dan meningkatkan efisiensi.

Untuk mengurangi tingkat kebosanan kebosanan dalam bekerja dapat dilakukan dengan cara

a. Memberikan waktu tenang kepada pekerja untuk refreshing, beristirahat, dan menyegarkan diri.

b. Menyediakan fasilitas yang memadai di tempat kerja, baik dalam hal yang berkaitan faktor fisik dan faktor sosial yang dapat meningkatkan kepuasan pada saat bekerja. Menurut Dahlias
\& Mariaty (2015), terdapat hubungan positif antara fasilitas kerja dan kepuasan kerja, apabila fasilitas kerjanya baik maka kepuasan kerja juga tinggi.

c. Melibatkan pekerja dalam proses pengambilan keputusan. Pelibatan pekerja dalam pengambilan keputusan dapat meningkatkan proses produksi atau kinerjanya (Leksono, 2014).

d. Perusahaan memberikan pekerjaan atau proyek baru yang lebih menantang sesuai dengan keahlian.

e. Melakukan aktivitas fisik seperti olahraga atau aktivitas booster breaks secara teratur

Peningkatan motivasi dan semangat dalam bekerja dapat dilakukan dengan menerapkan penilaian kinerja pekerja secara keseluruhan meliputi kemampuan kerja, pencapaian, kerajinan, disiplin, dan hal-hal khusus berdasarkan pada bidang dan tingkat pekerjaan yang dijabatnya dan memberikan reward berupa pemberian bonus atau insentif yang sesuai dengan prestasi yang dicapai oleh pekerja dan punishment berupa surat peringatan bagi pekerja yang bekerja di bawah standar. Hasil penelitian Febrianti (2014) menunjukkan bahwa terdapat pengaruh reward terhadap motivasi kerja. Semakin tinggi reward yang diberikan pada pekerja seperti bonus, pujian, penghargaan, kesejahteraan dapat meningkatkan motivasi pekerja. Hal ini juga berlaku pada saat pemberian punishment. Punishment diberikan sebagai alat pengendali agar kinerja pada organisasi dapat berjalan dengan baik. Peningkatan motivasi juga dapat dilaksanakan dengan mengadakan sesi tanya-jawab atau sharing dengan semua pekerja dan pimpinan setiap pekan.

Perbaikan pada pekerja sering lembur untuk menyelesaikan target dan pekerjaan yang belum selesai adalah perusahaan menentukan skala prioritas dan pembagian pekerjaan secara jelas kepada pekerja berdasarkan tingkat kepentingan dan deadline yang telah ditentukan sehingga pekerja mengetahui daftar pekerjaan "to do list' apa saja yang akan dikerjakan setiap harinya. Perusahaan menerapkan aturan lembur berdasarkan Keputusan Menteri Tenaga Kerja dan Transmigrasi No.102 Tahun 2004. Dalam Pasal 3 dinyatakan waktu kerja lembur hanya bisa dilakukan paling banyak 3 jam dalam 1 hari dan 14 jam dalam 1 minggu dan ketentuan waktu kerja lembur sebagaimana dimaksud dalam ayat (1) tidak termasuk kerja lembur yang dilakukan pada waktu istirahat mingguan atau hari libur resmi. Perbaikan juga dapat dilakukan dengan memberikan insentif atau upah lembur berdasarkan Keputusan Menteri No. 102/MEN/VI/2004, yaitu: (1) Perhitungan upah 
lembur karyawan harus berdasarkan pada upah bulanan. (2) Cara perhitungan upah dalam satu jam adalah $1 / 173 \times$ upah satu bulan.

Perbaikan lain yang berhubungan dengan kondisi pekerjaan adalah memberikan cuti tahunan yang dapat diambil oleh pekerja berdasarkan aturan dalam Pasal 79 dan 84 UUK Nomor 13 Tahun 2003 yang menyatakan bahwa setiap pekerja memperoleh sekurang-kurangnya cuti tahunan sebanyak 12 hari jika pekerja tersebut telah bekerja minimal 1 tahun di perusahaan. Cuti kerja efektif untuk mengurangi stress kerja karena dapat memulihkan kembali pikiran yang penat dan kondisi tubuh yang mulai jenuh dan lelah dalam bekerja (Ulfiyah et al., 2018). Langkah lainnya adalah memberikan orientasi dan pelatihan bagi karyawan baru di semua posisi dan memberikan pelatihan kerja baik dalam skill (desain bangunan) maupun soft skill secara rutin dan berkala contoh dalam satu tahun mengadakan dua kali pelatihan.

Usulan perbaikan yang berhubungan dengan indikator lingkungan sosial yang berkaitan dengan tanggung jawab yang besar terhadap kesejahteraan orang lain adalah perusahaan memberikan program kesejahteraan seperti pinjaman atau kredit dengan aturan yang jelas, asuransi kesehatan dan jaminan hari tua. Perbaikan terkait dengan kekhawatiran terhadap karir di masa depan (job insecurity) yaitu perusahaan meningkatkan dan mengembangkan kemampuan (skill), keterampilan, dan pengalaman pekerja dengan memberikan pelatihan kerja secara rutin, perusahaan membantu pekerja untuk mendapatkan sertifikasi keahlian arsitek (SKA) yang dapat dijadikan sebagai jaminan kompetensi seorang arsitek dan memberikan dukungan sosial dengan memberikan perhatian dan kepedulian oleh pemimpin kepada pekerja dalam bentuk mentoring dan role model. Perbaikan lingkungan sosial yang berhubungan dengan jenjang karir adalah dengan menjelaskan career path dalam perusahaan sehingga pekerja dapat menentukan goals dalam bekerja dan memotivasi diri untuk meningkatkan kinerja. Perusahaan juga dapat membuat desain program pengembangan karir pekerja melalui tiga tahap, yaitu tahap perencanaan, pengarahan, dan pengembangan. Apabila tidak ada jenjang karir yang jelas dalam suatu jabatan, maka perusahaan dapat memberikan program pengembangan karir dalam bentuk jaminan kesejahteraan bagi pekerja seperti peningkatan gaji.

\section{KESIMPULAN}

Hasil pengukuran menggunakan kuesioner MOQS menunjukkan bahwa terdapat pengaruh sangat signifikan dari variabel sistem kerja secara simultan terhadap stress kerja dan terdapat pengaruh signifikan dari variabel sistem kerja secara parsial terhadap stress kerja. Berdasarkan hasil perhitungan kontribusi efektif dari masing-masing variabel, diketahui bahwa kontribusi variabel terhadap stress kerja diurutkan dari yang paling tertinggi ke terendah adalah variabel kondisi pekerjaan, lingkungan sosial, karakteristik individu, kondisi organisasi, lingkungan fisik dan teknologi dan peralatan kerja. Usulan perbaikan diberikan kepada dua variabel yang memiliki nilai kontribusi tertinggi, yaitu kondisi pekerjaan dan lingkungan sosial. Usulan perbaikan tersebut disesuaikan dengan indikatorindikator dalam variabel yang menyebabkan stress kerja dan diharapakan perusahaan dapat mengimplementasikan usulan tersebut dengan mempertimbangkan aspek-aspek yang lain seperti anggaran dana yang akan digunakan, penjadwalan, dan lainnya.

\section{DAFTAR PUSTAKA}

Carayon, P., \& Hoonakker, P. (2004). Macroergonomic organizational questionnaire survey (MOQS). In Handbook of Human Factors and Ergonomics Methods (pp. 714-726). CRC Press. https://books.google.co.id/books?id=RApSg gShPc8C

Carayon, P., \& Smith, M. J. (2000). Work organization and ergonomics. Applied Ergonomics, 31(6), 649-662. https://doi.org/10.1016/S00036870(00)00040-5

Dahlias, A., \& Mariaty, I. (2015). Pengaruh Fasilitas Kerja terhadap Kepuasan Kerja Karyawan pada PT. Bank Riau Kepri Cabang Teluk Kuantan Kabupaten Kuantan Singingi. JOM FISIP, 3(2), 1-13. http://jom.unri.ac.id/index.php/JOMFSIP/arti cle/view/9731

Febrianti, S. (2014). Pengaruh Reward dan Punishment Terhadap Motivasi Kerja Serta Dampaknya Terhadap Kinerja (studi pada karyawan PT. Panin Bank Tbk. Area Mikro Jombang). Jurnal Administrasi Bisnis, 12(1), $1-9$.

http://administrasibisnis.studentjournal.ub.a c.id/index.php/jab/article/view/487

Ghozali, I. (2018). Aplikasi analisis multivariete dengan program IBM SPSS 23. Semarang: Universitas

Diponegoro. https://onesearch.id/Record/IOS2863.JATE N000000000218217

Leksono, H. (2014). Kebosanan Kerja: Peningkatan Stres dan Penurunan Kinerja karyawan dalam Spesialisasi Pekerjaan. Jurnal Jl Beka, 8(2), 14-18. 
https://jurnal.stie.asia.ac.id/index.php/jibeka/ issue/view/11

Lufri, L. (2004). Sumbangan Efektif Berpikir Kritis, Persepsi, Minat dan Sikap Terhadap Hasil Belajar. Jurnal Pendidikan Triadik, 8(1), 167-178. http://repository.unp.ac.id/1839/

Pertiwi, E. M., Denny, H. M., \& Widjasena, B. (2017). Hubungan Antara Beban Kerja Mental Dengan Stres Kerja Dosen Di Suatu Fakultas. Jurnal Kesehatan Masyarakat (Undip), 5(3), 260-268. https://ejournal3.undip.ac.id/index.php/jkm/a rticle/view/17220

Purnomo, H., \& Ferdianto, K. (2011). Desain Sistem Kerja Pada Pengrajin Mendong Dengan Pendekatan Ergonomi Makro. Prosiding Seminar Nasioanal Sains Dan Teknologi Ke-2 Fakultas Teknik Universitas Wahid Hasyim Semarang, 1(1), 12-17. https://publikasiilmiah.unwahas.ac.id/index. php/PROSIDING_SNST_FT/article/view/21 1

Setiyana, V. Y. (2013). Forgiveness dan stres kerja terhadap perawat. Jurnal IImiah Psikologi Terapan, 1(2), 376-396. http://202.52.52.22/index.php/jipt/article/vie w/1589

Simanjuntak, R. A. (2012). Pengaruh Sistem Kerja terhadap Stress Kerja dengan Penilaian Macroergonomi
Organizational
Questionnare Survei. Jurnal Teknologi Technoscientia, $\quad 5(1), \quad$ 80-88. https://ejournal.akprind.ac.id/index.php/tech noscientia/article/view/522

Siagian, S. (2003). Manajemen Sumber Daya Manusia. jakarta: PT Bumi Aksara

Stroebaek, P. S. (2013). Let's Have a Cup of Coffee! Coffee and Coping Communities at Work. Symbolic Interaction, 36(4), 381-397. https://doi.org/10.1002/symb.76

Sugiyono. (2018). Metode Penelitian Kualitatif untuk Penelitian yang Bersifat: Eksploratif, Enterpretif, Interaktif dan Konstruktif. bandung: $\quad \mathrm{CV}$. Alfabeta. https://onesearch.id/Record/IOS1.INLIS000 000000817593

Ulfiyah, N., Al Musadieq, M., \& Sulistyo, M. (2018). Analisis Peranan Cuti Kerja Dalam Rangka Mengurangi Stres Kerja Karyawan (Studi pada Karyawan PT. Perusahaan Daerah Air Minum). Jurnal Administrasi Bisnis, 61(1), 109-118.

http://administrasibisnis.studentjournal.ub.a c.id/index.php/jab/article/view/2553

Waber, B. N., Olguin Olguin, D., Kim, T., \& Pentland, A. (2010). Productivity Through Coffee Breaks: Changing Social Networks by Changing Break Structure. SSRN Electronic Journal, 1-22. https://doi.org/10.2139/ssrn.1586375 